\title{
O surgimento do institucionalismo norte-americano de Thorstein Veblen: economia política, tempo e lugar *
}

\author{
Marco Antonio Ribas Cavalieri ${ }^{* *}$
}

\begin{abstract}
Resumo
Tomando Thorstein Veblen como autor de um sistema original de economia política, este artigo explora as conexões entre o contexto social e a estrutura do método e da teoria que o fundador do institucionalismo propôs. Dentro disso, duas ideias se destacam: analisar o sistema vebleniano, tomando predominantemente por base o capítulo introdutório de seu livro de 1914, The Instinct of Workmanship and the State of Industrial Arts, aqui considerado como a mais clara exposição de sua economia política; e, em consonância com um conjunto de interpretações historiográficas do tempo e do lugar de Veblen, expor a estrutura da sua proposta teórico-metodológica como reflexo dessas condições contextuais.
\end{abstract}

Palavras-chave: Thorstein Veblen; Institucionalismo; Gilded age; Era progressiva; História do pensamento econômico.

\begin{abstract}
The emergence of Thorstein Veblen's north American institutionalism: political economy, time and place

Taking Thorstein Veblen as the author of an original system of political economy, this article explores the connections between the social context and the structure of his method and theory. Within this, two ideas take precedence: to approach the veblenian system predominately based on the introductory chapter of his 1914 book, The Instinct of Workmanship and the State of Industrial Arts, which is considered as the clearest exposure of his political economy; and, in compliance with a set of historical interpretations of his time and place, to show the structure of his methodological and theoretical proposal as a reflex of these contextual conditions.
\end{abstract}

Keywords: Thorstein Veblen; Institutionalism; Gilded age; Progressive era; History of economic thought.

JEL B310, B150.

Os anos que vão desde o fim da Reconstrução que se seguiu à Guerra Civil até a terceira década do século XX foram tempos profícuos para a literatura norteamericana, tanto quanto o foram para a vida material dos abastados. Se Mark Twain e Charles Dudley Warner eternizaram as impressões peculiares do início dessa época em The Gilded Age (1873), no outro extremo temporal, a obra-prima de Francis Scott Fitzgerald, The Great Gatsby (1925), mostra a permanência dos caracteres singulares desse período. Esses dois romances são ícones do poder que a literatura tem para explicitar aspectos marcantes do contexto em que foi produzida.

\footnotetext{
* Trabalho recebido em 5 de outubro de 2009 e aprovado em 10 de novembro de 2011.

** Professor Adjunto da Universidade Federal do Paraná, do Programa de Pós-Graduação em Desenvolvimento Econômico (PPGDE-UFPR), Curitiba, Paraná, Brasil. E-mail: cavaga@uol.com.br.
} 
Mas, assim como para os romances, anota-se já há algum tempo que a economia política também é um campo privilegiado de extrinsecação de aspectos fundamentais das realidades sociais. Paula, Cerqueira e Albuquerque (2001) fazem essa conexão em termos interessantes:

É que o romance moderno e a economia política, cada qual à sua maneira, são os símiles possíveis da grande aventura narrativa representada pela epopéia (sic). Se a epopéia clássica é o inventário das peripécias do heróiemblemático em sua complexa interação com o mundo, o romance e a economia política são as epopéias possíveis das peripécias de heróisproblemáticos: o indivíduo moderno condenado à liberdade e à alienação; a mercadoria-capital a que se atribui vida e que nesta condição subordina a vida real.

Com efeito, o objetivo deste trabalho é proceder a uma análise contextual da economia política de Thorstein Veblen. Assim, o fio condutor pelo qual o artigo deverá se guiar é o desvelar das provocações que o ambiente político-ideológico transborda sobre a economia política formada sob suas impressões. Mais especificamente, há de se colocar que o argumento central foi concebido sob a influência, ainda que não só, do chamado Programa Forte de Sociologia do Conhecimento ${ }^{1}$.

Nesse compasso, em relação aos estudos mais recentes sobre Veblen, tais como os de Hodgson (2004) e Tilman (2007), o presente artigo não rivaliza uma exegese que pretende enriquecer ou (re)construir o paradigma institucionalista. Já no confronto com uma análise mais antiga e enciclopedicamente rica em detalhes como a de Dorfman (1947) - a principal biografia de Veblen -, a diferença se faz notar em termos da inclinação mais epistemologicamente informada do texto aqui oferecido. Ponha-se que Dorfman não faz uma interpretação em síntese, com a marca de um princípio que tenha regido a concepção vebleniana de economia política. Ele mostra, sim, algo como uma narrativa de fatos e de ideias, sem, contudo, avançar conexões fundamentais.

Além disso, o texto sugere uma síntese da economia política de Veblen que elege sua obra de 1914, The Instinct of Workmanship and the State of Industrial Arts, como a melhor apresentação do sistema pensado pelo fundador do institucionalismo.

Para cumprir o que propõe, e pelo prisma da construção do contexto norteamericano, o texto socorre-se de algumas interpretações clássicas da historiografia do período em que Veblen viveu. Mormente, foram utilizadas as ideias de Richard

(1) O Programa Forte de Sociologia do Conhecimento é uma das tradições que formam o campo mais amplo da Sociologia do Conhecimento Científico. Uma boa síntese desse programa, oferecida por um economista, é a de Wade Hands (2001, p. 186-190). Na penúltima seção do artigo que está sendo lido, há uma breve exposição dos caracteres do Programa Forte que influenciaram este texto. 
Hofstadter (1955), consagradíssimo historiador dos Estados Unidos, e de Dorothy Ross (1991), que escreveu sobre as origens das ciências sociais naquele país, naquela época. Nisso encaixa-se também o surgimento de uma economia política que foi considerada como o primeiro "surto" de originalidade dos economistas norte-americanos.

Em face do exposto, de início, faz-se necessário mostrar a principal reivindicação metodológica de Thorstein Veblen. O autor de A Teoria da Classe Ociosa era um aguerrido descontente com a teoria econômica de seus dias, e por isso deu-se ao trabalho de realizar uma crítica das ideias e dos sistemas de economia política propostos até o seu tempo. Daí Veblen extrai o princípio metodológico capital que nortearia sua concepção de ciência pós-evolucionária. A seção seguinte deste trabalho dedica-se à abordagem do contexto dos Estados Unidos da Gilded Age e da Era Progressiva, dois rótulos utilizados para representar os anos entre o fim da Guerra da Secessão e o começo da década de 1920. Posteriormente, é fornecida uma síntese da economia política de Veblen, com o propósito de traduzir os aspectos essenciais de seu sistema. Por fim, e antes das notas conclusivas, expõe-se o cotejo entre o contexto e a economia vebleniana.

\section{A crítica e a reivindicação metodológica de Veblen: teleologia e a economia política pós-evolucionária}

Em certo sentido, Thorstein Veblen não foi um autor precoce. Sua primeira e indubitavelmente mais famosa obra, principal responsável por sua fama à época, e também nos dias de hoje, A Teoria da Classe Ociosa ${ }^{2}$, de 1899, vai à imprensa quando o autor norte-americano já contava mais de quarenta anos. Entretanto, se a TCO representou a escada para sua celebridade como intelectual radical, assinalese que, àquele tempo, Veblen já trabalhava, desde 1892, na edição do Journal of Political Economy, bem como já havia escrito alguns artigos bastante interessantes, além de ter resenhado muitas obras econômicas ${ }^{3}$. Um desses artigos, publicado em 1898, pode ser lido como o início de um trabalho de crítica sistemática às escolas de economia política que o precederam ${ }^{4}$. Em Why Is Economics not an Evolutionary Science?, Thorstein Veblen ([1898a], 1994) propõe que a economia se transforme em uma ciência pós-evolucionária, acompanhando uma tendência que, segundo sua visão, verificava-se tanto nas ciências naturais como nas sociais.

(2) Doravante TCO.

(3) Thorstein Veblen foi levado para o Departamento de Economia da Universidade de Chicago no mesmo ano de sua fundação, em 1892, pelo seu ex-professor James L. Laughlin, de Cornell. Ocupando um cargo hierarquicamente inferior ao de professor - research fellow -, Veblen era encarregado do trabalho de edição do Journal of Political Economy. Saiu de Chicago em 1906, quando já ocupava o cargo de professor assistente (Dorfman, 1947, p. 95).

(4) A crítica de Veblen pode ser dita sistemática porque se debruçou sobre todas as grandes tradições da economia política surgidas até os seus dias. 
Os clássicos - especialmente Smith, J. S. Mill e Cairnes -, bem como seus predecessores fisiocratas, foram o objeto de uma série publicada no Quarterly Journal of Economics entre 1899 e $1900^{5}$. O historicismo alemão, com foco no trabalho de Gustav Schmoller, também no Quarterly, foi escopo de outro artigo, que veio a público em 1901. A economia de Marx e seus seguidores mereceu análise em dois textos, de 1906 e 1907, no mesmo periódico ${ }^{6}$. Em 1909, o Journal of Political Economy publicou The Limitations of Marginal Utility.

\section{O ponto central da reivindicação metodológica de Veblen}

Nesse empreendimento intelectual, uma nota se destaca, na opinião advogada neste artigo, como a tônica do criticismo sistemático de Veblen: o combate aos conteúdos teleológicos das economias políticas. Nessa lógica, diz o crítico que, de modo fundamental, é a presença de um princípio teleológico dominante o traço da fronteira entre o que seria pré-evolucionário e a nova ciência, pós-evolucionária, franca de quaisquer métodos de construção teórica que implicassem processos causais finalísticos, isto é, regidos pela “causalidade do fim”.

No intuito de clarificar o significado da teleologia, o Dicionário de Filosofia de Nicola Abbagnano (2000, p. 457) define o termo como sinônimo de finalismo, e expõe: “[A teleologia é] a doutrina que admite a causalidade do fim. (...) Essa doutrina implica duas teses: $1^{\mathrm{a}}$ ) o mundo está organizado com vistas a um fim; $2^{a}$ ) a explicação de qualquer evento consiste em aduzir o fim para o qual este evento se dirige”. A origem das explicações de estirpe teleológica remonta a Anaxágoras (500-428 a.C.), que, segundo relatos de Platão e Aristóteles, teria, pela primeira vez, defendido a legitimidade de explanações de caráter teleológico ${ }^{7}$.

Exatamente nesse diapasão, e assumindo os economistas clássicos como um típico exemplo de pré-evolucionismo econômico, Veblen ([1898a], 1994, p. 61) explica: "Seu senso de verdade e substancialidade não é satisfeito com a formulação de uma sequência mecânica. O mais alto termo em sua sistematização de conhecimento é uma 'lei natural'. Tem-se a impressão de que esta lei natural exercita algum tipo de vigilância coercitiva sobre a sequência de eventos, dando

(5) The Preconceptions of Economic Science I, II e III.

(6) O socialismo já havia sido objeto de um artigo publicado em 1892, no qual a preocupação maior voltava-se para uma crítica ao pensamento de Herbert Spencer. A economia política de Marx foi analisada em The Socialist Economics of Karl Marx and His Followers I. O segundo texto, The Socialist Economics of Karl Marx and His Followers II, concentra-se nos autores marxistas do final do século XIX e início do século XX.

(7) Dentro da Filosofia, Abbagnano (2000) cita, ainda, como autores identificados com explicações de cunho teleológico - além de Platão e Aristóteles - os estoicos (segundo os quais a natureza faz as coisas do mundo em proveito do homem), Cícero, São Tomás de Aquino, Hegel, Schopenhauer, entre outros. 
estabilidade espiritual e consistência para a relação causal em qualquer conexão dada destes eventos"

Fazendo dessa crítica a baliza fundamental do edifício sobre o qual as ciências pós-evolucionárias estariam já se erguendo, o primeiro institucionalista nota o atraso da economia nesse processo. Enquanto a antropologia se mostrava como exemplo vivo de ciência pós-evolucionária entre as humanidades, a economia continuava “desamparadamente atrás dos tempos” (Veblen, [1898a], 1994, p. 56) ${ }^{9}$.

\section{Uma breve nota sobre as críticas das escolas de economia política em Veblen}

As teorias da economia política, para Veblen, estavam organizadas de modo que suas explicações aduzissem os fins para os quais os eventos socioeconômicos se dirigiriam, justamente no sentido da segunda tese implicada pela doutrina teleológica. E este será o acorde dominante da sua crítica.

Tal compreensão é bastante clara, por exemplo, na sua crítica à economia de Smith: "Tanto na Teoria dos Sentimentos Morais como na Riqueza das Nações existem várias passagens que testemunham sua contínua convicção de que existe, no curso natural das coisas, uma tendência benéfica conducente ao bem-estar, e o característico tom otimista em que ele defende que a liberdade natural não é mais que uma expressão desta convicção” (Veblen, [1899a], 1994, p. 114) ${ }^{10}$.

O mesmo parece aplicar-se claramente ao caso da economia política marxiana. Thorstein Veblen ([1907], 1994, p. 441) condena a inevitabilidade que, alegadamente, Marx impõe ao fim do sistema capitalista de produção, e nisto o esquema marxiano seria essencialmente diferente da economia pós-evolucionária: “Não há, por exemplo, garantia no esquema darwinista para asseverar a priori que

(8) As traduções livres a partir do inglês e que estão indicadas são do autor. Os trechos originais mais longos e importantes estão nas notas de rodapé. Neste caso, o excerto original é: "Their sense of truth and substantiality is not satisfied with a formulation of mechanical sequence. The ultimate term in their systematization of knowledge is a 'natural law'. This natural law is felt to exercise some sort of a coercive surveillance over the sequence of events, and to give a spiritual stability and consistence to the causal relation at any given juncture".

(9) Thorstein Veblen, dessa maneira, revelava seu entendimento de que o evolucionismo transcendia sua origem como naturalismo apenas, uma vez que sua estrutura conceitual, como método científico, constituía mesmo um sistema epistêmico, de conhecimento, o que seria reconhecido adiante por outros autores, como o destacado naturalista Ernest Mayr (Veiga, 2008, p. 245).

(10) Do original: "Both on the Theory of Moral Sentiments and in The Wealth of Nations there are many passages that testify to his abiding conviction that there is a wholesome trend in the natural course of things, and the characteristically optimistic tone in which he speaks for natural liberty is but an expression of this conviction". 
o interesse da classe trabalhadora os fará tomar uma posição contra a classe proprietária” 11 .

Mas, se em Smith e Marx as cores da teleologia são fortes demais para não serem tomadas como centrais, no marginalismo e na escola histórica alemã sua presença é aparentemente mais sutil, embora ainda dominante. No famoso texto de 1898, Veblen ([1898a], 1994, p. 73) chega a admitir que a discussão psicologicamente informada do braço austríaco do marginalismo carregava certo caráter "genético” (pós-evolucionário). Contudo, eles pecavam por adotar "uma concepção errônea da natureza humana”.

Assim, conquanto possa parecer que a crítica vebleniana ao marginalismo concentrava-se apenas na concepção errônea da natureza humana, mais adiante, em The Limitations of Marginal Utility, de 1909, Veblen avaliou esse erro como um preceito metafísico que impunha, inevitavelmente, a teleologia como aspecto proeminente do marginalismo ${ }^{12}$. A esse respeito, comenta: “A debilidade deste esquema teórico reside em seus postulados, que confinam a investigação às generalizações de ordem teleológica. (...) Tanto a escola clássica em geral, como sua variante especializada, a escola da utilidade-marginal, em particular, tomam como ponto de partida comum a psicologia tradicional dos hedonistas do começo do século XIX,...” (Veblen, [1909], 1994, p. 234)¹3. E, pouco depois, conclui: “A consequência imediata é que a teoria econômica resultante é de caráter teleológico (...). A relação procurada por esta teoria entre os fatos com os quais ela se ocupa é o controle exercido pelo futuro" (Veblen, [1909], 1994, p. 237) ${ }^{14}$.

Quanto à escola histórica alemã, no que tange ao trabalho de Gustav Schmoller, Veblen ([1901], 1994) admitiu que se chegou perto de uma análise "genética” da economia. Elogiou especialmente a disposição de Schmoller em embrenhar-se por temas culturais e antropológicos, algo que o próprio Veblen tomou como pauta e influência para seus estudos. No entanto, Schmoller teria

(11) Bem por isso Veblen será simpático a alguns marxistas revisionistas de fins do século XIX e crítico a autores como Karl Kautsky. Especificamente, Veblen cita, de maneira positiva, Eduard Bernstein, Conrad Schmidt (sic), Mikhail Tugan-Baranowski, Enrico Ferri e Antonio Labriola (Veblen, [1907], 1994). Original do trecho traduzido acima: "There is, for instance, no warrant in the Darwinian scheme of things for asserting a priori that the class interest of the working class will bring them to take a stand against the propertied class".

(12) Neste último texto, além do ramo austríaco, Veblen faz referência à economia de Jevons e Marshall, bem como ao sistema de John Bates Clark, seu ex-professor e o mais destacado marginalista norte-americano de fins do século XIX.

(13) Do original: "The infirmity of this theoretical scheme lies in its postulates, which confine the inquiry to the generalisations of the teleological order. (...) Both the classical school in general and its specialized variant, the marginal-utility school, in particular, take as their common point of departure the traditional psychology of the early nineteenth century hedonists,...”.

(14) Do original: "The immediate consequence is that the resulting economic theory is of a teleological character (...). The relation sought by this theory among the facts with which it is occupied is the control exercised by the future". 
pecado ao render-se ao conservadorismo que marcava a escola histórica alemã. Nesse sentido, Veblen ([1901], 1994, p. 272) afirma: “Nós teríamos, portanto, quase o direito de esperar que a erudição profunda e abrangente do Professor Schmoller nos campos da psicologia e da evolução cultural deveria desenvolver estes fatos para fins melhores do que o da pregação a respeito de uma consumação intrinsecamente desejável"15. A Alemanha fin de siècle era, portanto, o porto de chegada, o fim causal da teleologia schmolleriana.

É assim que Veblen abre espaço para construir sua economia pósevolucionária, não teleológica. Porém, antes de mostrar seu sistema em síntese, é preciso observar o contexto no qual nasceu sua economia política.

\section{Três ideias sobre uma América para ler Thorstein Veblen}

A tessitura da rede interpretativa sobre a qual se analisa a economia política de Veblen alude, necessariamente, a uma dicotomia política cujas origens retrocedem até os primeiros anos dos Estados Unidos independentes. O governo de George Washington, assim, vai marcar o tempo em que se instalariam mais delineadamente as duas tendências ideológicas capitais do pensamento político norte-americano: duas visões sobre qual seria o país a construir, e também sobre como fazê-lo. Essa oposição ideológica chama a atenção por uma existência relativamente cordata, mas na qual cada lado tinha seus "fins" - seu ideal de sociedade - e seus "meios" - os caminhos a percorrer para a consecução de sua filosofia social.

Thomas Jefferson, secretário de Estado, e Alexander Hamilton, secretário do Tesouro, personificariam as duas correntes. O primeiro, um liberal que advogava a participação mínima do governo na vida econômica, o localismo político, e alimentava a ideia da construção de uma nação de pequenos e médios fazendeiros, protótipos de um país mais homogêneo e nivelado ${ }^{16}$. Do lado de Hamilton, o Estado era chamado a auxiliar a edificação comercial e industrial dos Estados Unidos, capazes de rivalizar com os europeus a modernidade de sua produção, devendo, para alcançar tal objetivo, ser regido por uma aristocracia

(15) Do original: "We had, therefore, almost a right to expect that Professor Schmoller's profound and comprehensive erudition in the fields of psychology and cultural growth should turn these facts to better ends than a preachment concerning an intrinsically desirable consummation".

(16) Em Notes on the State of Virginia, de 1782, Jefferson fala sobre sua concepção da sociedade. Chama a atenção seu medo de que os Estados Unidos se transformassem numa nação industrial com sua classe operária, a antítese de um país de agricultores proprietários, pois: "A dependência gera subserviência e corrupção, sufoca a semente da virtude e prepara os instrumentos que servem aos desígnios da ambição”. Do que ele conclui: "Enquanto tivermos terra para trabalhar, então que nunca nos seja dado ver nossos cidadãos ocupados em uma bancada ou girando um fuso” (apud Blum et al., 1963, p. 143). 
socioeconômica que fatalmente formaria uma classe distante, em termos de abastança e poder político, do cidadão médio ${ }^{17}$.

Portanto, sob a influência desses dois celebríssimos founding fathers, clivam-se duas inclinações políticas. E, ainda durante o governo de Washington (1789-1797), que peremptoriamente pendeu para o lado de Hamilton, as tendências aglutinaram-se em dois partidos: o Federalista, elitista e mais intervencionista; e o Republicano, liberal.

Sendo os contornos dessa história relativamente bem conhecidos, resta observar que, mesmo com a eleição de Jefferson para a presidência, em 1800, os traços mais aristocráticos que o governo havia imprimido nos primeiros anos não se desfizeram facilmente. Vai ocorrer um gradual desmanche de certos privilégios aristocráticos, uma mitigação, mas não a eliminação. Surgiria a época que se chamou de o tempo da “ascensão do homem comum”, denominação associada ao período da presidência de Andrew Jackson (1829-1837). Mas, não obstante o fim do partido federalista em 1827, derrotado pela sua própria insistência em desprezar o oeste em expansão, os agricultores e o "americano médio”, os pensares mais aristocráticos se mantiveram como uma tendência política com a qual o liberalismo teve que se embater e se entender.

Porém, a reconfiguração do capitalismo a partir de meados do século XIX faria com que os ideais liberais de igualdade política e econômica passassem a ser, cada vez mais, suplantados pela ascensão de uma classe que dominaria os negócios e não demoraria a cooptar o poder político. Diante desse novo cenário, a instalação e a exacerbação do poder de uma elite político-econômica pareciam uma ameaça bastante séria, de modo a catalisar uma “inversão dos meios” políticos daquelas duas correntes ideológicas ${ }^{18}$.

\section{“Revolução de Status" e "Inversão dos Meios" em The Age of Reform de Richard Hofstadter}

A Gilded Age ${ }^{19}$ ficou marcada nos Estados Unidos pelo enriquecimento sem precedentes das classes altas norte-americanas ${ }^{20}$. Esse processo deu-se concomitantemente ao surgimento dos grandes trusts, que foram, junto com os

(17) O historiador Charles Seller (1985, p. 95) fala sobre o secretário do Tesouro: “Ambicioso e polêmico, esse homem queimava com uma visão de grandeza nacional. Sagazmente consciente da relação entre poder político e poder econômico, estava resolvido a promover o rápido crescimento econômico do país e a forjar laços políticos e econômicos entre o governo e os ricos e bem-nascidos”.

(18) Dorfman (1949, p. ix) diz que os liberais eram, antes de tudo, “antifeudalistas”, ou mais bem traduzido para aquele contexto: antiaristocratas.

(19) A historiografia norte-americana cita, em geral, a Gilded Age como o período entre 1865 e 1890, e a Era Progressiva como os anos entre o final desta última e 1920 (Edwards, 2006, p. 6).

(20) Pouco antes da crise financeira mundial recente, falava-se de uma nova Gilded Age, visto que um novo processo de forte concentração de renda estava em curso nos Estados Unidos (Uchitelle, 2007). 
nomes dos capitães da indústria, tais como Carnegie, Rockefeller, Vanderbilt, o signo desses tempos e foi resultado desse surgimento. Mas, juntamente com o sucesso das classes altas, nascem, em paralelo, os movimentos “descontentes”.

O surgimento dos clamores reformistas da Gilded Age deita raízes nos protestos dos produtores rurais do último terço do século XIX. Membros de movimentos como o Granger e o Populista reclamavam dos preços praticados pelos monopólios ferroviários, pelos monopsônios distribuidores de carne e de grãos, e dos juros praticados pelos bancos.

Contudo, um famoso estudo de Douglass North (apud Whaples; Betts, 1995, p. 509) acabou por constatar que não houvera uma queda substancial dos preços, nem aumento exagerado das tarifas e dos juros ${ }^{21}$. Assim, as condições sobre as quais as celeumas dos “descontentes agrários” se apoiavam, na verdade, eram apenas aparentes. Nesse sentido, em outro célebre artigo, Anne Mayhew ([1972], 1995) sugeriu, concordando com a avaliação de North, que os protestos não teriam sido motivados pelos preços em si, mas pela "crescente importância dos preços” (Mayhew, [1972], 1995, p. 516). O mundo agrário norte-americano - até os tempos da Guerra Civil pouquíssimo integrado e isolado em “ilhas” regionais estava sendo incorporado a um sistema comandado por grandes corporações dirigidas a partir de um centro distante e impessoal. Os fazendeiros, nesse processo, tornavam-se cada vez menos os senhores de seus próprios negócios.

Essa interpretação de Mayhew é a projeção, na seara econômica, de uma das teses que celebrizou The Age of Reform de Richard Hofstadter (1955), talvez a mais discutida interpretação historiográfica da política dos tempos em que Veblen viveu.

Hofstadter (1955), da mesma forma, analisa os descontentamentos agrários, mostrando como os protestos surgiram no campo. Mas é quando fala sobre o movimento progressista, tipicamente de classe média, intelectual e urbano, que surge a ideia da “revolução de status". A Era Progressiva, então, é marcada pela transferência do protagonismo dos protestos para as classes médias das cidades.

No entanto, o que desperta maior interesse nesse cenário é a constatação de que, assim como no campo, essa classe média urbana também estava desfrutando do enriquecimento nacional. Desse modo, Hofstadter (1955, p. 137), em similitude com o que seria posteriormente avançado por Mayhew, constata: "Em um sentido estritamente econômico estes homens não estavam ficando mais pobres como classe, mas sua riqueza e poder estavam se tornando insignificantes em comparação com as novas eminências da riqueza e do poder. Eles estavam menos

(21) North, D. Growth and welfare in American Past. New York: Prentice Hall, 1966. 
importantes, e sabiam disso" ${ }^{22}$. E ainda ilustra o sentimento da classe média com um testemunho da época que poderia, certamente, ser de um leitor da TCO: "Nossos sobre-endinheirados vizinhos causam uma deflação relativa de nossas personalidades. (...) Em todos os lugares, (...), nós encontramos as boas e as más realizações dos milionários, e aparentemente nos ressentimos tanto de umas como das outras. Nossos cavalos de montaria são ultrapassados pelos seus automóveis de alta potência. Nós somos obrigados a engolir sua poeira” (Hofstadter, 1955, p. 147$)^{23}$.

A saída para essa situação de “deflação de status”, que em muito remete à perda de poder político, surge quase como lógica na memória de uma democracia popular tão cara aos antiaristocratas norte-americanos. Acontece, portanto, algo como uma “inversão dos meios” dos combates da dicotomia político-ideológica norte-americana. Os temerosos da instalação de uma classe destacada, mais rica e ao mesmo tempo mais embrenhada no poder político, no governo, os receosos do surgimento e instalação de uma aristocracia nos Estados Unidos, que cerraram fileiras no liberalismo de Jefferson e de Jackson, agora, de acordo com Hofstadter (1955, p. 233):

... de maneira mais relutante do que entusiástica, o americano médio tendeu mais e mais a confiar na regulação governamental, a procurar na ação governamental um contraponto ao poder dos negócios privados. Em seu ressentimento contra as incursões das organizações de negócios sobre suas sensibilidades morais e seus valores individualistas, ele começou a apoiar a organização governamental e a aceitá-la mais prontamente do que ele gostaria de ter feito antes da idéia de que o alcance do governo deveria ser estendido. (...), ele olhava para o governo federal como seu último recurso para o controle dos negócios, assim ironicamente dando apoio para outro passo da destruição daquele sistema de valores locais e descentralizados no quais ele também acreditava ${ }^{24}$.

E essa “inversão de meios” refletiu-se no surgimento do que se considerou, à época e mesmo hoje, como o aparecimento da economia política mais original norte-americana.

(22) Do original: "In a strictly economic sense these men were not growing poorer as a class, but their wealth and power were being dwarfed by comparison with the new eminences of wealth and power. They were less important, and they knew it".

(23) Do original: "Our over-moneyed neighbors cause a relative deflation of our personalities. (...) Everywhere, (...), we meet the millionaire's good and evil works, and seem to resent the one as much as the other. Our jogging horses are passed by their high-power automobiles. We are obliged to take their dust”.

(24) Do original: “... reluctantly rather than enthusiastically, the average American tended more and more to rely on government regulation, to seek in governmental action a counterpoise to the power of private business. In his resentment against the incursions of business organization upon his moral sensibilities and his individualistic values, he began to support governmental organization and to accept more readily than he had been willing to do before the idea that the reach of government must be extended. (...), he looked to the federal government as his last resource for the control of business, thus ironically leading support to another step in the destruction of that system of local and decentralized values in which he also believed". 


\section{O surgimento da economia política “original” nos Estados Unidos e o pluralismo teórico da Gilded Age e da Era Progressiva}

Charles Dunbar (1876, p. 137), o primeiro a ocupar uma cadeira acadêmica de Economia Política nos Estados Unidos, escreveu que, àquele tempo: "Não somente nenhuma escola americana de escritores de economia política se estabeleceu, (...), mas também nenhuma contribuição reconhecida ao desenvolvimento desta ciência pode ser apontada em comparação àquelas feitas pelos escritores franceses, ou àquelas que os alemães estão fazendo agora" ${ }^{\text {25 }}$. Passados pouco mais de vinte anos, outro analista, o professor A. F. Weber (1899, p. 260), assinalava uma evolução no pensamento econômico norte-americano. Com o trabalho de Francis Amasa Walker (1840-1897), a economia nos Estados Unidos parecia ter entrado numa fase em que formulações mais originais estariam sendo propostas.

A despeito da discussão sobre o ineditismo das ideias de Walker - um economista eminentemente tributário da escola clássica -, a verdade é que ele pode ser destacado como o primeiro de um movimento que vai se tornar bastante influente na Gilded Age e na Era Progressiva ${ }^{26}$. Nessa linha, o historiador Vernon Parrington ([1927], 2008) surpreende a intenção da obra de Walker:

Francis A. Walker veio a ser o campeão autonomeado do industrialismo, o economista oficial da Gilded Age, e precursor de uma longa linha de fomentadores do dogma econômico. (...) e como uma autoridade apologista dos lucros empresariais, ele prestou ao capitalismo um serviço que em alguma medida apagou o seu pequeno pecado ricardiano de crença no livrecomércio $^{27}$.

O grupo que pode ser colocado ao lado de Walker, formado pelos defensores do novo capitalismo de fins do século XIX, é adequadamente chamado de “apologistas americanos”. A página eletrônica sobre história do pensamento econômico da New School University (2008) descreve:

“Apologistas Americanos” é o único termo que conseguimos cunhar para
descrever os economistas e cientistas sociais arquiconservadores de fins do
século XIX e início do XX. Embora tenham existido economistas mais
antigos de reputação considerável, como Henry C. Carey e Daniel Raymond,

(25) Do original: "Not only has no American school of writers on political economy been established, (...), but no recognized contribution to the development of the science can be pointed out in any way comparable to those made by the French writers, or to those which the Germans are now making”.

(26) A grande realização de Walker, que lhe rendeu a alusão como primeiro economista norte-americano original, foi o tratamento dado pelo autor à questão clássica do fundo de salários. Sobre isso, ver Bell (1982).

(27) Do original: "Francis A. Walker was to be the self-appointed champion of industrialism, the official economist of the Gilded Age, and a forerunner of a long line of academic purveyors of economic dogma. (...) and as an authoritative apologist for entrepreneur profits he rendered a service to capitalism that quite erased his little Ricardian peccadillo of free-trade prejudice". 
uma economia americana propriamente dita surgiu somente na década de 1870 com o trabalho de Francis A. Walker. Ao longo dos quarenta anos que se seguiram, ou quase isso, o cenário da economia americana foi dominado por uma "ortodoxia” que seguiu o que foi plantado por Walker. Esta ortodoxia era teoricamente frouxa, flutuando entre a teoria econômica clássica e a neoclássica. Foi em seus trabalhos aplicados e na postura política que eles se distinguiram mais nitidamente ${ }^{28}$.

Esses autores, liberais como os economistas clássicos e neoclássicos da Europa, contrapunham-se à intervenção estatal reclamada pelos movimentos reformistas. Porém, o mesmo texto continua e ressalta: “É importante notar que a maioria dos apologistas americanos não fazia o tipo liberal da escola de Manchester. (...) O que os apologistas tinham que defender era o novo capitalismo industrial - dominado por 'trusts' corporativos monopolistas” ${ }^{29}$ (New School University, 2008). O liberalismo, então, passa a ser, cada vez mais e predominantemente, embora não de forma exclusiva, a "arma”, o “meio" dos que defendiam o grande capital e, paralela e consequentemente, dos que amparavam a formação e o reforço da aristocracia político-econômica.

Desde darwinistas sociais, como William Graham Sumner, até economistas profundamente apegados à tradição do senso comum britânico e da economia política clássica mais pura, como o chefe de Veblen em Chicago, James Laughlin, todos eles tinham como tônica dos seus discursos o clamor pelo liberalismo, algo que naquele tempo era acompanhado pelos elogios aos êxitos econômicos dos grandes capitalistas, os “capitães da indústria” de Veblen ${ }^{30}$.

No outro lado da contenda, reuniam-se os reformistas que, numa heterogeneidade teórica maior que a dos apologistas, encarnavam aquele processo

(28) Do original: “The 'American Apologists' is the only term we could come up to describe late 19th Century and early 20th Century American arch-conservative economists and social scientists. Although there had been earlier American economists of considerable reputation, such as Henry C. Carey and Daniel Raymond, a distinctive American economics only really came into "being" in the 1870s with the work of Francis A. Walker. For the next forty years or so, the American economics scene was dominated by an "orthodoxy" which followed on the heels of Walker. This orthodoxy was rather theoretically loose, hovering between Classical and Neoclassical economic theory. It was in their applied work and policy stance that they distinguished themselves most clearly".

(29) Do original: "It is important to note that most of the American apologists were not Manchester School-type liberals (...) What the apologists had to defend was the new industrial capitalism - dominated by prominent monopolistic 'trust' corporations...”.

(30) Laughlin (1884, p. 512-513), destarte, fornece um exemplar bastante interessante dos argumentos e do estilo dos apologistas em Workingmen's Grievances: "Por exemplo, quando eu vejo artigos de luxo muito caros serem usados, ou sou atingido na rua por respingos de lama vindos de uma vistosa carruagem de um rico proprietário de uma estrada de ferro, então pela lógica, eu sou obrigado a raciocinar deste modo: tudo aquilo que constitui o grande consumo deste homem rico é evidência de que em algum lugar está sendo empregado o trabalho de alguém. É uma impossibilidade física para Jay Gould ou para o Sr. Vanderbilt consumirem toda a sua renda; na verdade, apenas uma pequena parte é exaurida em consumo pessoal. (...) A lama respingada das rodas da carruagem do milionário pode despertar minha raiva e inveja, mas por outro lado, estando eu à procura de emprego, isso significa que em algum lugar devem existir fábricas para a manufatura de carruagens e arreios, e que lá deve existir o capital para empregar o trabalho". 
de apelo ao Estado narrado por Hofstadter. Richard Ely (1887, p. 117) é um ótimo modelo desse movimento. Em seus apontamentos, ressalta:

O tempo presente é daqueles nos quais a evolução da sociedade está ocorrendo de maneira mais veloz do que o usual, e é evidente que nós precisamos de uma economia política positiva e construtiva, exigência que a antiga economia política não pode atender. Deixe o leitor considerar por um momento a época na qual seus grandes mestres, Quesnay, Turgot e Adam Smith viveram. Foi a última metade do século XVIII, quando o progresso da indústria era retardado por uma porção de instituições antigas, válidas em seu tempo, sem dúvida, mas que se tornaram antiquadas. O clamor dos homens que pertenciam a esse tempo era "removam as barreiras, limpem o caminho para novas formas sociais!”. O trabalho que os grandes economistas defenderam durante esse período foi apropriadamente destrutivo e negativo. Não deve nos surpreender o fato de que quando recorremos aos nossos antigos livros de economia política para procurar por conselhos referentes a medidas práticas, a principal lição que aprendemos é "NÃO FAÇA". Manifestamente, o chamado da nossa época é "FAÇA"31.

À “inversão de meios”, deve-se somar a anotação de um notável pluralismo teórico como aspecto proeminente do cenário da economia política de fins do século XIX e começo do século XX (Barber, 2003; Rutherford, 2003; Morgan e Rutherford, 1998). Marginalistas e classicistas, darwinistas sociais, independentes e ecléticos dos mais variados tipos defendiam posições antagônicas, que se intersectavam, completavam-se e dirigiam-se às defesas das diversas concepções da sociedade norte-americana. Os mais diversos "meios" teóricos, feitos ferramentais para a advocacia das mais diferentes posições políticas, portanto, eram tomados para cumprir uma pletora de "fins", para a defesa de diferentes filosofias sociais sobre o futuro dos Estados Unidos. Sobre a economia política dos últimos anos do século XIX, naquele momento já percebida como um campo em que florescia alguma originalidade, William Barber (2003, p. 244) afirma: “A economia americana não mais poderia ser desprezada como atrasada. Existia muito dinamismo. Um componente proeminente da nova realidade nacional era sua grande abertura para o pluralismo" 32 .

(31) Do original: "The present time is one in which the evolution of society is proceeding with more than its usual rapidity, and it is evident that we need a positive constructive political economy, and this requirement the old political economy cannot meet. Let the reader consider for a moment the age in which its great masters, Quesnay, Turgot, and Adam Smith, lived. It was the latter half of the eighteenth century, when the progress of industry was retarded by a multitude of old institutions, good in their day, doubtless, but then antiquated. The cry of men who understood their time was, "Remove the barriers! Clear the way for new social forms!" The work which great economists advocated during that period was very properly negative and destructive. It ought not then to surprise us that when we go to our old textbooks of political economy to seek advice in reference o practical measures, one chief lesson which we can learn in 'DON'T'. Manifestly, the call of our age is 'DO'”.

(32) Do original: "No longer could American economics could be dismissed as retarded. There was dynamism aplenty. A striking component of the new national reality was its very openness to pluralism". 
O próprio Thorstein Veblen produziu-se sob este pluralismo teórico, ainda que chame muito a atenção sua originalidade, ao rejeitar, conforme já visto anteriormente, os ferramentais teóricos que as grandes escolas de economia política precedentes lhe ofereciam. Mas o pensar social sob a influência das ideias evolucionistas era já bastante popular, em função da ciência social spenceriana nos Estados Unidos, representada por Sumner. O fundador do institucionalismo toma, para a construção de seu sistema, um evolucionismo bastante diferente do que embasou estes dois últimos conservadores, absolutamente opostos a Veblen no espectro político-ideológico. Todavia, ainda assim, eram todos eles tributários do evolucionismo. Sumner chegou a ter problemas na religiosa Yale, em razão de suas ideias pró-darwinismo. Pela outra trincheira, Lester Ward, importante sociólogo reformista que recebeu com grandes elogios a publicação da TCO, também é visto por muitos como um intelectual influenciado fortemente pelo evolucionismo.

Chame-se pluralismo ou, como preferem alguns, incerteza metodológica, a verdade é que esse período de variedade no ferramental econômico, sem a precedência categórica de uma corrente, estendeu-se até o período entreguerras. Como quase ubiquamente sabido, seria apenas depois do segundo grande conflito mundial que, com base nos Estados Unidos principalmente, o paradigma neoclássico-marginalista instalar-se-ia como mainstream da disciplina.

\section{O excepcionalismo na ciência social norte-americana}

Dorothy Ross (1991) é autora de um denso estudo sobre o surgimento das ciências sociais nos Estados Unidos, onde ela destaca o papel dominante da ideologia do "excepcionalismo” na formação do pensamento social daquele país. A formação da ciência social norte-americana, então, estaria profundamente marcada pela ideia de que os Estados Unidos ocupavam um lugar excepcional ou, em outras palavras, um lugar privilegiado entre as nações do mundo. Nos termos de Ross (1991, p. xiv): "Eu acredito que a ciência social americana deve seu caráter distintivo ao seu envolvimento com a ideologia nacional do excepcionalismo americano, a idéia de que a América ocupa um lugar excepcional na história, baseada em seu governo republicano e na oportunidade econômica"33. A autora faz questão de notar que essa é uma tendência central, não única, no aparecimento da ciência social norte-americana ${ }^{34}$. Contudo, aparentemente, pouquíssimas ideias escapam ao enquadramento de Ross nessa ideologia do excepcionalismo.

O excepcionalismo mais purista é herdeiro mesmo do ideal peregrino, da imagem fundamental da realização do "reino" na terra, da "terra prometida”,

(33) Do original: "I believe that American social science owes its distinctive character to its involvement with the national ideology of American exceptionalism, the idea that America occupies an exceptional place in history, based on her republican government and economic opportunity".

(34) Para Ross (1991), as ciências sociais norte-americanas teriam se formado entre os anos 1870 e 1929. 
ideário tão comum ao pensamento cristão. Adiante no tempo, a revolução da independência vai ser absorvida justamente como uma instanciação desse imaginário. Em Ross (1991, p. 22-23): “Quando a independência nacional foi ganha, protestantes apaixonados identificaram a república Americana com o advento do período milenarista que deveria levar à salvação final da humanidade e ao fim da história. O progresso americano poderia ser o desenrolar da semente milenarista, ao invés de [apenas] um processo de mudança histórica” ${ }^{\text {„3 }}$. Para Ross (1991), assim como para o historiador do pensamento econômico Joseph Dorfman (1949), o período do antebellum, em sua ciência da sociedade, é notoriamente carregado desse excepcionalismo. Os norte-americanos apropriaram-se do pensamento europeu, desde a filosofia do senso comum - predominante no ensino superior dominado pela religião - até o Iluminismo, francês ou britânico, transfigurando-os em um matiz bem mais otimista, alvissareiro na exata medida da promessa “milenarista”. Por essa ótica é que Ross (1991, p. 49) afirma que os norte-americanos vão preferir o otimismo smithiano à ciência sombria de Malthus e Ricardo.

A Gilded Age, com suas tensas e profundas transformações, porém, vem ameaçar a doutrina do excepcionalismo mais puro. Segundo Ross (1991, p. 53), isso se deu com base em dois ângulos. Primeiro, a ciência assume, a passos seguros, seu lugar como uma das mais respeitadas instituições humanas. Nessa esteira vêm justamente os novos conhecimentos da estirpe do evolucionismo, que terminam por desacreditar ideários de cunho providencialista, como o excepcionalismo. Em segundo lugar, as mudanças econômicas colocam em posição defensiva o pensamento de realização de um ideal otimista, pois que, na maré das transformações sociais, surgem de forma mais destacada os “descontentes”, os desfavorecidos pelas mudanças. Nas palavras de Ross (1991, p. 57): “O que a Guerra [Civil] ensinou foi logo multiplicado várias vezes pelos efeitos disruptivos da industrialização. Talvez o fato mais duro que eles tiveram que encarar foi a existência de uma classe trabalhadora permanente, crescentemente vinculada através dos processos mecânicos ao trabalho assalariado e às vicissitudes do ciclo econômico"36.

Ao que tudo parecia, a ciência social norte-americana, ao contrário do que havia feito através da metamorfose do pensamento europeu em cores otimistas, pela primeira vez teria que lidar com a ideia de descontinuidade. É nesse ambiente

(35) Do original: "When national independence was won, fervent Protestants identified the American Republic with the advent of the millennial period that would usher in the final salvation of mankind and the end of history. American progress would be the unfolding of the millennial seed rather than a process of a historical change".

(36) Do original: "What the [Civil] war taught was soon compounded many times over by the disruptive effects of industrialization. (...) Perhaps the hardest fact they had to face was the existence of a permanent working class, increasingly tied by machine processes to wage labor and to the vicissitudes of the business cycle". 
social que surge, então, a economia, a ciência política e a sociologia propriamente norte-americanas.

Mas a autora de The Origins of American Social Science interpreta que, se tudo levava a crer que os cientistas sociais norte-americanos iriam, inevitavelmente, haver-se com as descontinuidades históricas, abrindo mão da presença da doutrina excepcionalista em seus pensamentos, não é o que ocorre.

É nesse período, da Gilded Age, que nasce a economia apologista. Ross (1991) explicitamente situa Walker e Sumner como representantes da economia e da sociologia que, naqueles idos, vão absorver a história como pré-requisito da ciência social, mas, ao mesmo tempo, fazendo-a conformada aos ideais de realização excepcionalista. Tanto Walker, com sua economia predominantemente liberal em um tempo onde os conflitos entre trabalho e capital se acentuavam, quanto Sumner, com sua ode às realizações dos mais ricos e dos capitães da indústria, são representantes das tendências que não só, conforme visto na seção anterior, vão tomar o liberalismo como “meio", como também vão procurar modelar a história à continuidade da doutrina excepcionalista, ainda que mitigada, transfigurada, retrabalhada (Ross, 1991, p. 95).

Só como adendo, vale mencionar que Ross (1991) analisa o marginalismo, que para ela aparece com maior premência na Era Progressiva, da mesma maneira. Sobre Irving Fisher e Bates Clark, Ross (1991, p. 186) aduz: "Entre o determinismo tradicional de Fisher e o excepcionalismo dinâmico de Clark, os teóricos marginalistas na América tiveram uma base ampla para ignorar a história”37.

Muitos reformistas, para Ross (1991), também se encaixavam, grosso modo, no ideal excepcionalista. Na seção destinada ao cotejo entre o sistema vebleniano e a visão do excepcionalismo avançada por Ross, a ideia de que Thorstein Veblen pode ser visto por esse prisma será contestada. E isso envolve não só o reforço de sua reivindicação evolucionária, como também sua tentativa de propor uma economia não teleológica, sendo que a negação do finalismo é mesmo uma negação de qualquer doutrina do tipo excepcionalista.

Mas, antes disso, seja uma síntese da economia política pós-evolucionária de Veblen.

\section{0 sistema vebleniano de economia política}

Na única obra mais extensa escrita por um autor brasileiro sobre Veblen, Leonardo Monastério (1998, p. 19) considera: “... o sistema teórico de Veblen

(37) Do original: "Between the traditional determinism of Fisher and the dynamic exceptionalism of Clark, marginal theorists in America had ample grounds for ignoring history”. 
guarda uma unidade; sua metodologia - reflexo de sua visão epistemológica serve também de base para as suas críticas à teoria econômica tradicional. Sua compreensão do ser humano está de acordo com seus preceitos metodológicos; e também a análise que ele faz da evolução dos sistemas econômicos é compatível com o restante da sua obra”.

Destarte, aqui se aceita a coesão como um aspecto forte que sobressai na leitura das diversas obras de Thorstein Veblen. Entretanto, seria apenas em 1914 quinze anos depois de lançar a TCO e dez após The Theory of Business Enterprise -, com a publicação de The Instinct of Workmanship and the State of Industrial Arts ${ }^{38}$, que seu autor apresentaria, de maneira mais clara e bem estruturada, uma espécie de “capítulo metodológico”. O próprio Veblen considerava ser esta a sua obra mais importante (Dorfman, 1947, p. 324; Monastério, 1998, p. 26). A propósito, logo depois da publicação da TCO, o planejado era partir para a escrita de TIWO, um sinal da visão conexa que Veblen tinha de seu sistema (Dorfman, 1947, p. 197; Jorgensen e Jorgensen, 1999, p. 249) ${ }^{39}$. O livro sintetiza o curso mais famoso que Veblen ministrou nas instituições por onde passou, “Economic Factors in Civilization”.

\section{O sistema de economia política (não teleológico) de Thorstein Veblen}

Duas categorias fundamentais articulam o sistema de economia de Veblen: instintos e instituições.

A primeira preocupação em TIWO é esclarecer em que sentido a palavra instinto estaria sendo usada. Os instintos são propensões inatas provocadoras de ações humanas. Mas, para se chegar a uma definição mais específica, o antigo institucionalista vai diferenciar os instintos do que ele chama de ações tropismáticas. Estas últimas seriam aquelas ações humanas provocadas por meros reflexos, como o famoso exemplo de se retirar a mão de algo que está quente ao ponto de queimar a pele. Já os instintos, por sua vez, envolvem algum grau de deliberação consciente. Quando uma inclinação fundamental da natureza humana exige que o homem pense, raciocine na direção da elaboração de ações - ou de uma sequência delas - para atingir um fim determinado, pode-se estar na presença de um instinto. O outro requisito necessário para a identificação de um instinto é que a propensão provocadora de ações deve ser irredutível a outras inclinações, localizadas em um nível hipoteticamente mais básico. Em realidade, o conceito de instinto em Veblen somente fica inteiramente claro quando o autor de TIWO vai sugerir quais são, em sua visão, essas inclinações fundamentais - duas delas são tratadas logo abaixo (Veblen, [1899b], 1994; [1914], 1994).

(38)Doravante TIWO.

(39) Porém, antes de escrevê-lo, Veblen lançou The Theory of Business Enterprise, publicado em 1904. Seus biógrafos indicam que o TIWO foi escrito entre os anos de 1909 e 1913, com alguns períodos de interrupção em sua composição (Dorfman, 1947, passim; Jorgensen e Jorgensen, 1999, passim). 
Em seguida, Veblen vai explicar as origens desses instintos. Neste ponto, reside uma ligação fundamental que o autor de TIWO estabelece entre sua ciência social e o evolucionismo naturalista darwiniano. Os instintos são, então, um resultado do processo evolutivo, são caracteres presentes nos homens, transmitidos hereditariamente, e que devem ter sido fundamentais na sobrevivência da espécie.

Essa ideia já estava presente no trabalho de Veblen desde a sua contestação do princípio clássico de que o trabalho é desprazeroso (irksomeness of labor). Em um artigo de 1898, The Instinct of Workmanship and Irksomeness of Labor, o professor de Chicago argumenta que a aversão ao trabalho, parte fundamental do "homem econômico" clássico, contrariaria a "lei da seleção natural”. E desafia: se o homem é naturalmente avesso ao trabalho, então falta explicar “... como ele teria alcançado sua emancipação da lei da seleção natural” (Veblen, [1898b], 1994, p. 79). O ser humano, portanto, seria dotado de um instinto do trabalho eficaz, uma inclinação à realização de trabalhos úteis, que Veblen ([1898b], 1994, p. 80) define como: “... um senso classificador de propósitos, pela força do qual toda a futilidade da vida ou da ação é desagradável...”40. Para Veblen, o homem procura evitar esforços na direção de tarefas, de trabalhos, de ações que em nada contribuem, em última instância, para a sobrevivência do indivíduo ou da espécie. Ken McCormick (2006, p. 10) sugere dois exemplos interessantes, nos quais o instinto do trabalho eficaz pode ser percebido. Primeiro, o "pequeno sentimento de culpa” que os seres humanos percebem quando estão completamente desocupados, desperdiçando tempo. Segundo, a rejeição por procedimentos burocráticos que, real ou aparentemente, parecem não ter nenhum objetivo prático ulterior.

Além do instinto do trabalho eficaz, em TIWO, a inclinação parental é apresentada como a única propensão humana capaz de disputar com aquele a primazia de ser o instinto fundamental (Veblen, [1914], 1994, p. 25). A inclinação parental é a propensão humana ao cuidado com as gerações vindouras, não só no tocante ao bemestar da prole, entendida como relação de consanguinidade, mas também ao senso de preservação da vida humana como espécie ${ }^{41}$.

Sendo assim, Veblen parte para a explicação de como os seres humanos projetam meios para cumprir os fins postos pelas inclinações instintivas. A categoria instituições nasce precisamente desta construção de meios. Nos dizeres de Veblen ([1914], 1994, p. 6): “As finalidades da vida, então, os propósitos a serem realizados, são designados pelas propensões instintivas dos homens; mas os caminhos e os meios

(40) Do original: “... a discriminating sense of purpose, by force of which all futility of life or of action is distasteful...”.

(41) Os dois outros instintos básicos da teoria vebleniana são: a curiosidade desinteressada e o instinto predatório (Veblen, [1906], [1899b], 1994). 
para atingir o que as proclividades instintivas fazem valer a pena são um assunto da inteligência"42. E, no contexto do desenvolvimento desses meios:

Quanto mais alto o grau de inteligência e quanto maior o corpo de conhecimento disponível em qualquer comunidade dada, mais extensiva e elaborada será a lógica dos caminhos e meios interpostos entre esses impulsos [as propensões instintivas] e sua realização, e mais multifacetado e complicado será o aparato de convenções e recursos empregados para acompanhar tais fins que são instintivamente dignos de valor (Veblen, [1914], 1994, p. 6) ${ }^{43}$.

Fincados os objetivos básicos pelos instintos, os seres humanos desenvolvem ações que constituem meios para cumprir as metas fornecidas pelas propensões instintivas. Tais meios, no desenrolar da história humana, multiplicam-se numa pletora de conjuntos de ações, e, numa figura útil à compreensão em foco, podem ser entendidos como formadores de "vetores de ações sequenciais”, que têm como alvo perseguir um dado objetivo instintivo. Tais vetores vão se tornando mais complexos e mais variados à medida que as relações sociais desenvolvem-se historicamente. Logo, o sistema de geração de meios para a perseguição dos fins também vai ampliando seu grau de complexidade.

As instituições, dentro desse sistema, nascem da habituação, do caráter consuetudinário que algumas das ações ou vetores de ações gerados acabam assumindo. Deve-se dizer que as ações ou sequências delas tornam-se instituições quando sua adoção como modo de agir, ou mesmo de pensar, se torna tão automática para os indivíduos ou grupos que os mesmos não consideram mais a origem, os motivos ulteriores das ações e sequências de ações realizadas. Instituições são modos de agir ou de pensar que, embora nascidos da necessidade humana de se perseguir algum fim determinado, acabam adquirindo uma dinâmica própria, isto é, tornam-se fins em si mesmas. Veblen ([1914], 1994, p. 7) explica: "Sob a disciplina da habituação esta lógica e aparato de caminhos e meios encaixam-se em linhas convencionais, adquirem a consistência de costume e prescrição, e então tomam um caráter e força institucionais"

É nesse processo de institucionalização que reside a mais forte não teleologia da estrutura teórica do sistema vebleniano. Segundo as próprias palavras do autor:

(42) Do original: "The ends of life, then, the purposes to be achieved, are assigned by man's instinctive proclivities; but the ways and means of accomplishing those things which the instinctive proclivities so make worth while are a matter of intelligence".

(43) Do original: "The higher the degree of intelligence and the larger the available body of knowledge current in any given community, the more extensive and elaborate will be the logic of ways and means interposed between these impulses [the instinctive propensities] and their realisation, and the more multifarious and complicated will be the apparatus of expedients and resources employed to compass those ends that are instinctively worth while”.

(44) Do original: "Under the discipline of habituation this logic and apparatus of ways and means falls into conventional lines, acquires the consistency of custom and prescription, and so takes on an institutional character and force". 
Enquanto elementos do esquema aprovado de conduta e busca estes caminhos e meios convencionais tomam seus lugares como fins aproximados dos esforços. Donde, no que se segue no curso da incessante habituação, como a atenção está habitualmente focada nesses fins aproximados, eles ocupam o interesse de tal forma que comumente jogam os propósitos ulteriores para o fundo e com freqüência deixam que se perca qualquer sinal deles; como pode acontecer, por exemplo, com a aquisição e o uso do dinheiro. Segue-se que em muito da conduta humana apenas estes fins aproximados surgem na consciência como os objetos de interesse e objetivos dos esforços, e certos caminhos e meios convencionalmente aceitos vêm a ser adotados como princípios definitivos do que é bom e certo; enquanto o propósito ulterior de tudo aquilo só é trazido à mente ocasionalmente, algo que nem sempre acontece, e como um pensamento tardio, por um esforço de reflexão (Veblen, [1914], 1994, p. 7-8) ${ }^{45}$.

Nesse raciocínio, os meios tomam o lugar dos objetivos preexistentes, os instintivos, e tornam-se fins em si mesmos. Essa é a dinâmica própria de que se falou acima. E, para além disso, tal processo tem, obviamente, um caráter recorrente e complexo, dando causa a uma variedade muito grande de ações e vetores de ações que

perseguem fins e, ao mesmo tempo, que se transformam em fins dando mote a uma nova geração de meios que podem, evidentemente, também se transformar em fins, e assim por diante $e^{46}$.

Um ponto importante é a observação de Veblen ([1914], 1994, p. 19) quanto ao caráter quimérico de atribuir qualquer otimalidade à construção inteligente das ações e, especialmente, à sua institucionalização: "Mas não há garantia para assumir que cada uma dessas sucessivas mudanças no esquema institucional progressivamente permita meios e caminhos mais fáceis, certos ou imediatos para que as inclinações instintivas atinjam seus fins, ou que aquela fase de habituação em operação seja, em qualquer ponto dado da sequência de mudança, mais ajustada para o funcionamento sem problemas destes instintos do que as fases anteriores”47.

(45) Do original: "As elements of the approved scheme of conduct and pursuit these conventional ways and means take their place as proximate ends of endeavour. Whence, in the further course of unremitting habituation, as the attention is habitually focused on these proximate ends, they occupy the interest to such an extent as commonly to throw their own ulterior purpose into the background and often let it be lost sight of; as may happen, for instance, in the acquisition and use of money. It follows that in much of human conduct these proximate ends alone are present in consciousness as the object of interest and the goal of endeavour, and certain conventionally accepted ways and means come to be set up as definitive principles of what is right and good; while the ulterior purpose of it all is only called to mind occasionally, if at all, as an afterthought, by an effort of reflection".

(46) Veblen ([1914], 1994, p. 18) observa sobre o desenvolvimento de instituições: “... os elementos habituais da vida humana mudam incessante e cumulativamente, resultando em um crescimento contínuo e prolífico de instituições”.

(47) Do original: "But there is no warrant for assuming that each or any of these successive changes in the scheme of institutions affords successively readier, surer or more facile ways and means for the instinctive proclivities to work out their ends, or that the phase of habituation in force at any given point in this sequence of change is more suitable to the untroubled functioning of these instincts than any phase that has gone before". 
A Figura 1 pretende reproduzir uma síntese do sistema vebleniano sugerido no “capítulo metodológico” de TIWO. Essa ilustração apresenta três adições importantes ao esquema delineado acima.

Em primeiro lugar, ela destaca o papel do próprio conjunto de instituições na seleção dos vetores de ações - ou das próprias ações - que irão se tornar costumeiros ou institucionalizar-se. Faz-se importante assinalar aqui que a seleção de instituições ocorre mediada por um processo guiado pelo ambiente social que, no bojo do conjunto das instituições existentes, cria mecanismos de coerção social, de valoração das ações, com base naquilo que se encaixa em seu status quo. Ademais, esse é um mecanismo de autopreservação das instituições já existentes. Num dos momentos mais metodológicos da TCO, Veblen ([1899b], 1994, p. 188) explica: “As instituições não são somente o resultado de um processo seletivo e adaptativo que molda os tipos espirituais dominantes de atitudes e aptidões; elas são ao mesmo tempo métodos especiais de vida e de relações humanas, e, portanto, são por sua vez fatores efetivos de seleção"48.

Figura 1

Esquematização do sistema vebleniano

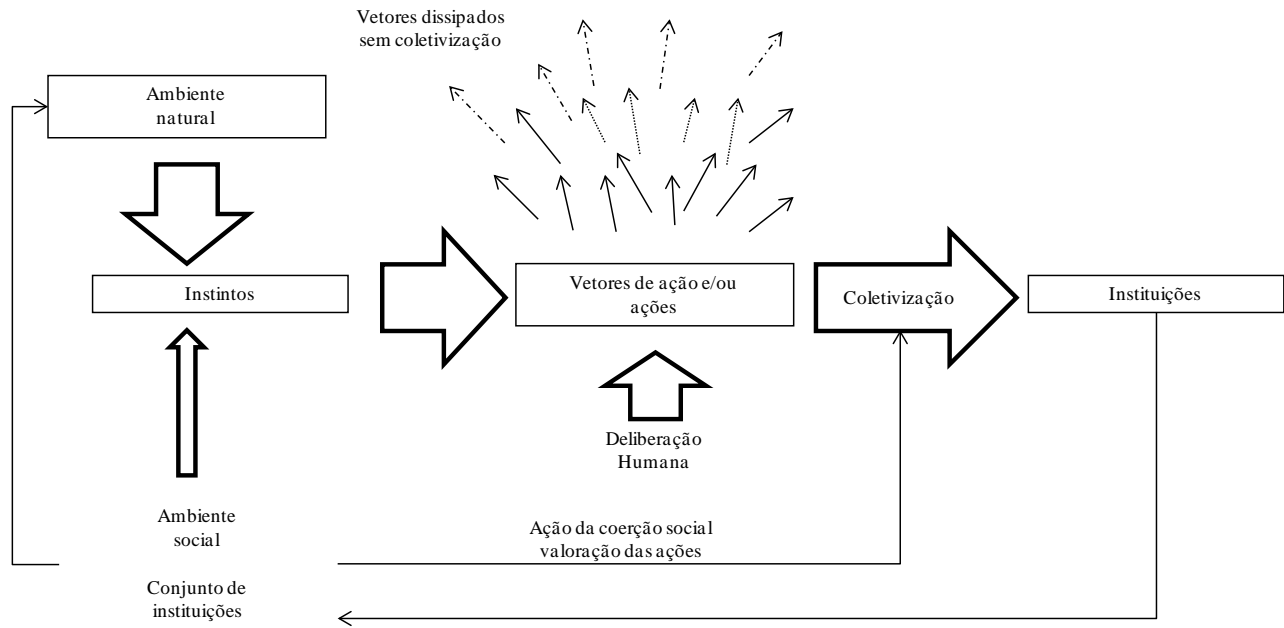

Fonte: Elaboração própria, baseado em Veblen ([1914], 1994).

Em segundo lugar, é preciso notar que os instintos são influenciados pelo conjunto de instituições existentes. Porém não na forma de hereditariedade, no nível biológico, mas como uma estrutura sobre a qual os instintos têm um ambiente mais ou menos propício para sua predominância como finalidade. A história geral

(48) Do original: "Institutions are not only themselves the result of a selective and adaptative process which shapes the prevailing or dominant types of spiritual attitudes and aptitudes; they are at the same time special methods of life and human relations, and are therefore in their turn efficient factors of selection". 
da humanidade, tema dos outros capítulos de TIWO mas já exposta anteriormente por Veblen em artigos e mesmo na TCO, mostra como, em épocas diferentes, os instintos predatório e do trabalho eficaz encontraram terrenos mais ou menos favoráveis ao seu afloramento como inclinação prevalecente da vida humana (Veblen, [1914], 1994, passim) ${ }^{49}$.

Por fim, é razoável que o ambiente social afete o ambiente natural e, por esta via, seja causa de mudanças na esfera instintiva. No entanto, não se pode deixar de anotar que os tempos históricos nos quais se opera a afetação do ambiente natural em direção aos instintos são bastante diferentes, no sentido de um horizonte temporal deveras mais longo, em comparação ao tempo em que ocorrem as relações de causa e efeito entre o ambiente social e as instituições.

\section{Evolucionismo darwinista e não teleologia}

Uma primeira observação sobre o sistema vebleniano, conforme descrito acima, deve ser concernente à sua coadunação com o esquema mais geral da metodologia implicada pelo trabalho naturalista de Charles Darwin. Este, aliás, é um ponto já bastante reforçado na literatura especializada em Veblen ${ }^{50}$. A coadunação a que se faz referência é aquela segundo a qual o darwinismo analisa os fenômenos de acordo com a estrutura tripartite de: (1) geração de variedade; (2) hereditariedade ou transmissão de caracteres; e (3) seleção.

A geração de variedade encontra-se tanto no nível dos instintos, visto que o processo evolutivo necessariamente se dá a partir de uma multiplicidade de características, como sobre as ações e sequências delas, criadas a partir da deliberação inteligente na perseguição dos fins instintivos ou institucionais. A transmissão hereditária encontra-se no caráter consuetudinário presumido para que hábitos e instituições se estabilizem, primeiro como meios, e em alguns casos como fins, bem como na transmissão hereditária dos instintos. Por fim, a seleção imbrica-se e comanda todo o processo, novamente, tanto no plano instintivo como no institucional. Nesta última esfera, a seleção opera sobre a variedade de ações e sequências de ações transformando-as, eventualmente, em hábitos e em instituições.

A segunda observação é que a negação peremptória da teleologia precisa ser compreendida em dois sentidos.

(49) Veblen ([1914], [1898b], 1994) divide a história da humanidade, grosso modo, em quatro etapas. A selvageria pacífica, o barbarismo, a Era da Manufatura (Era of Handicraft) e o tempo da indústria das máquinas (machine industry). Para cada uma das etapas históricas Veblen discute a prevalência de uma ou outra inclinação instintiva.

(50) Hodgson (2008) faz um excelente resumo dessa visão. 
De início, Veblen apresenta um sistema que ultrapassa o recurso à teleologia, instalando uma conexão íntima, via evolução darwiniana, entre as esferas natural e social. Nessa lógica, dizia o próprio naturalista: “... nós estamos acostumados a olhar para o progresso como a regra normal na sociedade humana; mas a história refuta isso (...) Nós precisamos lembrar que o progresso é não uma regra invariável” (Darwin apud Hodgson, 2004, p. 44) ${ }^{51}$. Por um lado, conforme assinalado acima, não há nada que garanta a otimalidade das ações deliberadas como meios para perseguir os fins instintivos. Por outro, os ambientes social e natural como estruturas cambiantes dificultam a adaptação tanto dos instintos como das instituições em cada momento histórico. O processo evolutivo, portanto, é neutro quanto ao bem-estar humano ou quaisquer outros fins.

Depois, a possibilidade da transformação fundamental de instituições como “meios” para instituições como "fins” confere maior complexidade ao processo social, na medida em que estas se tornam possíveis e muito comuns na compreensão de Veblen ([1914], 1994, p. 25), resultando na proliferação de divergências entre as ações humanas e quaisquer fins determinados pelas inclinações instintivas. Outrossim, mesmo que os instintos sejam selecionados como úteis para a adaptação humana ao ambiente, eles podem dar mote a ações completamente desarmônicas à sobrevivência da espécie humana ${ }^{52}$. Dentro dessa premissa é que os caminhos múltiplos são possíveis para a história humana e, nessa reivindicação vebleniana, recusa-se, portanto, qualquer sistema teórico que proponha o alcance de um estado finalístico, seja ele um horizonte de curto ou longo prazo, seja ele, também, o estado no qual a sociedade se encontra, em um dado momento histórico.

É assim que a economia política vebleniana se pretende não teleológica, ao propor um sistema que permite a análise da sociedade como uma busca que não depende da postura de uma finalidade, como uma teoria que contempla a apreciação da história humana enquanto construção de uma rede institucional sem convergências necessárias. Thorstein Veblen traz para a economia a possibilidade de fins múltiplos, que mimetiza na esfera social a complexidade da evolução do mundo natural, tal qual aparece na conjectura da árvore evolutiva de Darwin ("I think”) sobre a evolução das espécies (Figura 2).

(51) Darwin, C. R. The descent of man, and selection in relation to sex. v. 1. London and New York: Murray and Hill, 1871. E, no original: “...we are apt to look at the progress as the normal rule in human society; but history refutes this (...) We must remember that progress is no invariable rule”.

54 Nesse ponto, em particular, o instinto predatório, útil na competição sexual e na alimentação humanas, imiscuído com o instinto do trabalho eficaz, pôde resultar no costume institucionalizado de respeitar o trabalho na guerra como uma ocupação socialmente nobre. 
Figura 2

Conjectura de Darwin sobre a evolução das espécies - anotações de seu caderno

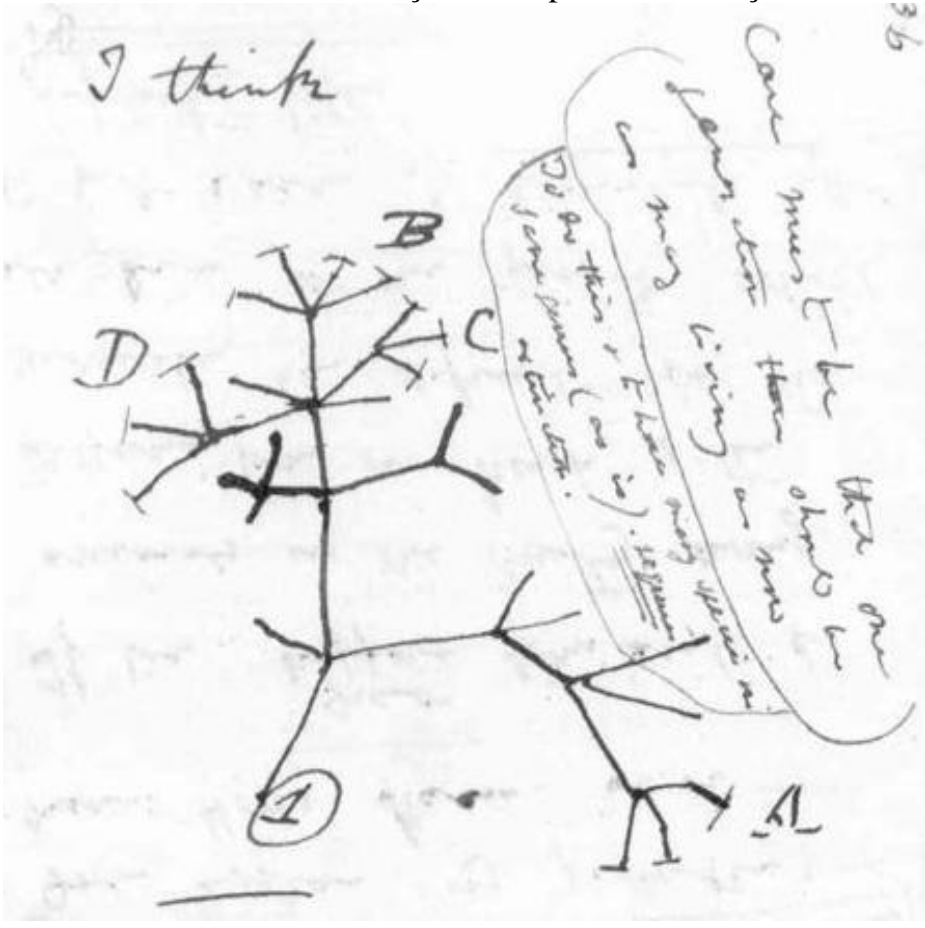

Fonte: http://www.age-of-the-sage.org.

\section{0 tempo, o lugar e o sistema de economia política de Thorstein Veblen}

Alinhavados um contexto e um esboço geral da economia política institucionalista de Thorstein Veblen, chega o momento de tomá-los em conjunto, delineando suas interferências e intersecções e, enfim, desvelando suas relações de afinidade. Nesse tom, Steven Shapin e Simon Schaffer (1985), dois historiadores da ciência, em detalhadíssimo estudo sobre o debate que envolveu Thomas Hobbes e Robert Boyle no século XVII, indicam os objetivos típicos de um estudo calcado no Programa Forte de Sociologia da Ciência. Em primeiro lugar, eles preocupamse com as declarações dos cientistas acerca do método, ou seja, sobre como a ciência deve ser adequadamente conduzida. Depois, considera-se que este método tem relação com outras práticas sociointelectuais fora da ciência, tais como os costumes sociais ou as ideologias prevalecentes. Em conjunto, deve-se situar as controvérsias científicas e as teorizações no contexto social, ampliado para além da ciência e da sociedade científica mais restrita. Enfim, Shapin e Schaffer (1985, p. 14) afirmam: “... nós também queremos dizer algo mais quando usamos o termo 'contexto social'. Nós temos a intenção de mostrar o método científico como 
formas de cristalização da organização social e um meio de regular a interação dentro da comunidade científica" ${ }^{\text {}}$.

Em geral, nos estudos do Programa Forte, as ideologias políticas assumem um lugar de destaque. Segundo os autores dessa corrente, as formas e visões do mundo social, o imaginário social e sua expressão política em termos das ideologias são, necessariamente, estruturas de pensar que transbordam para outras áreas da atividade humana. David Bloor ([1976], 1991, p. 76), iniciador dessa tendência nos estudos da ciência, aduz: “As ideologias sociais são tão presentes que se tornam uma explicação óbvia do porquê de nossos conceitos assumirem as estruturas que têm. Ademais, o emprego tácito dessas ideologias como metáforas pode ser visto como impossível de se evitar" ${ }^{\text {. }}$.

Se isso acontece no caso da física, como o estudo de Shapin e Schaffer procura mostrar, e no caso da matemática e da epistemologia da ciência em Bloor ([1976], 1991), não há razão para que a economia política escape dessas influências. Aliás, como coloca Wade Hands ([1997], 2008), isso parece fortificarse no caso de uma ciência social como a economia.

Dentro desse contexto, afirme-se o ponto central da percepção de Veblen a propósito da sociedade e, logo, sobre como se deveria proceder à construção de um sistema teórico que se debruça sobre esta realidade:

As direções múltiplas e indeterminadas que os processos históricos podem tomar são a característica mais forte do sistema social. Por isso, a economia política deve reconstruir-se sobre pressupostos que permitam, e mais do que isso, engendrem análises não teleológicas.

Discutam-se, agora, os encaixes entre a estrutura teórica vebleniana, sua reivindicação evolucionária, seu tempo e seu lugar.

I

Seja primeiro o excepcionalismo norte-americano destacado por Ross (1991). Se a ideologia do pré-destino norte-americano é uma característica proeminente do pensamento social daquele país, deve-se dizer que, nos tempos de Veblen, isto se desvelou de forma amplificada no movimento dos apologistas americanos, ao se fundar o que era visto àquele tempo como uma economia política originalmente norte-americana.

(53) Do original: “...we also mean something else when we use the term "social context”. We intend to display scientific method as crystallizing forms of social organization and as means of regulating interaction within the scientific society”.

(54) Do original: "The social ideologies are so pervasive that they are an obvious explanation of why our concepts have the structures that they do. Indeed the tacit employment of these ideologies as metaphors would seem almost impossible to avoid". 
As ideias do economista considerado por Vernon Parrington como o iniciador desta corrente, Francis Walker, significavam, na opinião de Ross (1991, p. 84), um avanço em relação ao pensamento dos cientistas sociais da geração anterior, com maior afetação religiosa. Mas, ainda assim, expressavam apenas um ajuste da salvação do excepcionalismo norte-americano frente aos perigos que se contrapunham às leis econômicas “naturais”. Embora acusado de ser simpático aos trabalhadores pelos conservadores mais aguerridos, uma vez que defendia a legitimidade da formação de sindicatos, Walker, ao fim e ao cabo, era outro economista que bradava pelo laissez passez, ou, em outras palavras, pelo funcionamento desimpedido das leis naturais da economia. Para além disso, era um típico apologista das realizações dos grandes industriais, dos trusts fathers da Gilded Age.

Sumner, por sua vez, tomado por Ross (1991, p. 85) como um dos fundadores da sociologia nos Estados Unidos, vai no mesmo passo. Utilizando a ideia spenceriana da sobrevivência do mais apto e a ligação de tal visão com o evolucionismo darwiniano, ele exalta o novo capitalismo de concentração e tornase um dos paladinos do elogio à classe alta norte-americana. Para Sumner, tanto este enriquecimento de classe quanto a oportunidade, aberta a qualquer um capaz de um esforço obstinado para levar uma vida frugal e inclinada à poupança, eram sinais que caracterizavam os Estados Unidos como a terra do cumprimento da promessa excepcionalista.

E, mesmo Bates Clark, que no início de sua carreira pareceu aproximar-se da defesa de uma distribuição mais equânime da renda, na segunda fase de seu trabalho, aparece como um dos pilares da defesa do status quo da Gilded Age e da Era Progressiva. Sua tese distributiva, calçada no marginalismo europeu, afirmava que para cada agente econômico o sistema capitalista garantia como renda sua contribuição ao produto total, traduzindo-se em uma ode ao estado das coisas, à sociedade de mercado, que tinha nos Estados Unidos seu mais pujante representante. Nesse sentido, Bates Clark, antigo professor e apoiador de Veblen, mesmo sendo inserido por alguns, como é o caso de McGerr (2003), no rol dos economistas reformistas, tornou-se alvo do ácido criticismo do fundador do institucionalismo, que, sem dúvida, o via como mais um dos apologistas. Veblen ([1908], 1994, p. 190-191) dispara sobre seu ex-professor:

As premissas do Sr. Clark, (...) são as [premissas] padrão da Escola Clássica Inglesa (incluindo a vertente Jevons-austríaca). Essa escola de economia apóia-se no terreno pré-evolucionário da normalidade e da "lei natural” (...). Sua tarefa é trazer os fatos para a estrutura desse sistema de categorias "naturais”. Em conjunto com este propósito científico do economista 
taxonômico, está o propósito pragmático de encontrar e advogar uma direção conveniente para a política ${ }^{55}$.

Dessa cena, é impossível inferir que Veblen não tenha carregado uma impressão forte para seu sistema, o qual, como argumentado acima, é pautado essencialmente pela negação da teleologia. Embora tenha ele, em sua crítica sistemática à economia política, centrado fogo nas escolas europeias, tal fato se dava porque Veblen não percebia novidade no pensamento norte-americano de nenhum dos apologistas. E isso é algo com o que se pode concordar, pois o trabalho de todos eles flutuava entre os pensamentos clássico e neoclássico, ou, ainda, constituía uma variante local do evolucionismo spenceriano, como no caso de Sumner. Thorstein Veblen, portanto, na visão aqui exposta, entreverou-se com esse pensamento extremamente conservador, representado pelos apologistas. Sua crítica à economia política, desse modo, dirigiu-se às ideias europeias porque estas formavam as premissas sobre as quais os norte-americanos pousaram seu excepcionalismo, sua teleologia, ou melhor, sua apologia do estado das coisas.

É de lembrar que Veblen trabalhou na edição do Journal of Political Economy, ocupação na qual travou contato com uma pletora de textos de apologistas, inclusive os de seu chefe, James Laughlin. Também se retome que o economista que reivindicava o avanço da economia em direção ao pósevolucionismo escreveu, exclusivamente, para periódicos que eram editados e circulavam nos Estados Unidos. Sua audiência e seus adversários, portanto, eram primordialmente seus conterrâneos ${ }^{56}$.

Ross (1991, passim) interpreta Veblen essencialmente como um socialista, como uma exceção ao “revisionismo liberal” típico dos autores da Era Progressiva, um revisionismo que procurava recolocar ou resgatar o excepcionalismo norteamericano dos cursos históricos que pareciam defletir o passo seguro dos Estados Unidos. Mas, ao mesmo tempo, Ross (1991, p. 217) inclui Veblen entre os excepcionalistas. Para a autora, o socialismo vebleniano também era uma forma de fazer o país cumprir sua fortuna.

Embora seja inegável a simpatia de Veblen em relação ao socialismo, não obstante seus recorrentes desvios em direção a um agnosticismo político, a marca maior da obra do fundador do institucionalismo não é no sentido de propor uma práxis política. Isso, de maneira alguma. Se ele concorda com o revisionismo de

(55) Do original: "Mr. Clark's premises, (...) are the standard ones of the classical English School (including the Jevons-Austrian wing). This school of economics stands on the pre-evolutionary ground of normality, and 'natural law' (...). His task is to bring facts within the framework of this scheme of 'natural' categories. Coupled with this scientific purpose of the taxonomic economist is the pragmatic purpose of finding and advocating the expedient course of policy”.

(56) Roy Weintraub (1992) é um economista que argumenta sobre a importância das comunidades científicas localizadas na formação da ciência econômica. 
marxistas como Eduard Bernstein e Mikhail Tugan-Baranovski e, ao mesmo tempo, condena a doutrina da inevitabilidade do socialismo de autores como Karl Kautsky, não se pode, a partir daí, afirmar que Veblen definitivamente defendia o socialismo. No texto de 1907, justamente sobre a discussão das revisões marxistas, ele afirma: "E, no tocante às doutrinas marxistas da exploração, não há lugar, em bases darwinianas, para um direito natural à totalidade do produto do trabalho. $\mathrm{O}$ que pode ser argumentado sobre esse ponto baseado simplesmente em causa e efeito diz respeito à questão de qual esquema de distribuição vai auxiliar ou prejudicar a sobrevivência de um dado povo ou uma dada civilização",57 (Veblen, [1907], 1994, p. 444-445). Daí que, de acordo com a opinião esposada aqui, o que resulta das doutrinas de Veblen é, sobretudo, um agnosticismo em relação a soluções ideais ${ }^{58}$.

Sua obra, em geral, reflete essa metódica fuga de propostas práticas, em paralelo a uma ambiguidade, um desvio de previsões, sempre retomado ao final dos seus tratados, ponto que, aliás, foi reconhecido por Ross (1991, p. 214).

De tudo isso, é possível dizer que, se Veblen tivesse marcado seu trabalho essencialmente por um apelo político, seja ao socialismo, seja a outra solução política, poder-se-ia daí deduzir um argumento como o ventilado por Ross, a saber: o de que Veblen encaixava-se no mesmo rol de outros cientistas sociais inclinados à preservação da ideologia do excepcionalismo norte-americano. Contudo, em vista do excepcionalismo exacerbado de seus principais adversários intelectuais, os apologistas americanos, da metodologia darwinista por ele utilizada, bem como de suas tão energéticas declarações a respeito da negatividade da teleologia na ciência, dificilmente torna-se factível aceitar Veblen como parte de uma tradição tal qual o excepcionalismo, que tem no finalismo sua mais forte característica.

Em suma, mesmo que Veblen não tenha avançado decisivamente propostas superadoras, e mesmo que tenha se atido a uma análise criticamente descritiva, ainda que embasada em uma firme metodologia, é de admitir que:

(57) Do original: “And, as bearing on the Marxian doctrines of exploitation, there is on Darwinian ground no place for a natural right to full product of labor. What can be argued in that connection on the ground of cause and effect simply is the question as to what scheme of distribution will help or hinder the survival of a given people or a given civilization".

(58) Outro ponto pelo qual se pode julgar Veblen como defensor de alguma forma de socialismo é o que faz referência ao seu texto sobre o estabelecimento de um soviet de técnicos, publicado em 1919 no The Dial, periódico radical, onde atuava como um de seus editores. Porém, aqui se concorda com a avaliação de Janet Knoedler e Anne Mayhew (1999), que identificam o texto da revista como um artigo semipopular que refletia uma preocupação presente naquela época entre os próprios engenheiros, que almejavam seu lugar como uma classe fundamental na sociedade da Era Progressiva. Dessa monta, Veblen era um (metodologicamente informadíssimo) "repórter dos eventos de seu tempo”, muito mais do que o propugnador de uma revolução levada a cabo por engenheiros, muito mais também do que alguém que estaria fazendo uma previsão acerca de tal revolução (Knoedler; Mayhew, 1999, p. 269). 
A forte presença da teleologia num campo ideológico tão diametralmente oposto aos argumentos de Veblen deve ser encarada como uma condição de possibilidade, ou uma estrutura intelectual provocadora de sua ânsia evolucionária, do argumento central de seu apelo pós-evolucionário.

\section{II}

Em segundo lugar, trate-se da questão da estrutura geral do sistema vebleniano e sua relação com o imaginário ideológico da época.

Recupere-se aqui que o sistema vebleniano é, enfim, um sistema que se constrói sobre esta noção de finalidades e meios para persegui-las. E, nessa estruturação de meios, que são produto da deliberação humana, criados para perseguir finalidades, gera-se um sistema complexo, com alto grau de indeterminação e que procura mimetizar a realidade intrincada do sistema social real. A transformação fundamental de meios em fins e, adicionalmente, a crescente complexificação do sistema social, resultado da geração variada de ações e de sua institucionalização, implica e busca permitir uma análise não teleológica da sociedade. Assim, em síntese e em reforço: o método evolucionário de Veblen provoca a não teleologia, os finais múltiplos, e, por conseguinte, gera uma teoria que engendra análises não finalísticas.

Nesse particular, abre-se a possibilidade de ler o sistema vebleniano como um “espelho da sociedade”, como uma “cristalização” das formas observáveis no imaginário ideológico. A “inversão de meios” entre os reformistas, herdeiros dos liberais do início da república, e os conservadores é algo que não pode ser visto como trivial para o observador informado daquele período. Ao se tomar uma ou outra finalidade política, no sentido de se construir um ou outro ideal de sociedade, a primeira impressão que sobressalta desse processo é que meios são e devem ser cambiáveis. São construções que se ajustam, mais ou menos, em cada ambiente social, para os fins a que se propõem. A citação de Ely remete exatamente a isso. E, precisamente na troca de posições entre reformistas e conservadores, essa mutabilidade, esse caráter movediço dos meios se mostra em todo o seu radicalismo: os meios que antes eram para um dado fim tornam-se os meios para a consecução de outro fim. Com isso, inultrapassavelmente, certezas são solapadas, verdades há muito conhecidas sofrem um processo de superação, precisam ser superadas, e tal não se realiza sem algum desconforto no nível do imaginário social.

É necessário notar também que, no tempo de Veblen, para além desse processo central de inversão dos meios das ideologias que dominavam o cenário político norte-americano, aparece um sem-número de posições na ciência social utilizando os mais variados ferramentais: marginalismo, classicismo, 
evolucionismo social, marxismo e, como maior agente complicador, as posições ecléticas.

Finalmente, o casamento não necessário entre meios e fins, o uso de variados meios para variados fins, assim como a "inversão de meios" - no âmbito mais propriamente político - são então marcas que atingem indelevelmente o sistema vebleniano. E isso se dá especialmente de duas formas.

Em primeiro lugar, através da estruturação do sistema vebleniano como articulado em bases de “meios” e "fins”. E, considerando que todo esse cenário combina com as profundas transformações econômicas pelas quais os norteamericanos passavam, diga-se, sinteticamente, que:

A compreensão do sistema socioeconômico através da inter-relação entre meios e fins, da diversidade de meios mais ou menos específicos para cada tempo histórico e da não otimalidade necessária entre meios e fins pode ser entendida como um "espelhamento", uma variedade de "cristalização" científica do imaginário político-ideológico do fim do século XIX nos Estados Unidos.

O segundo modo pelo qual a economia política vebleniana pode ser surpreendida como produto do seu tempo diz respeito à sua ligação e derivação da biologia evolucionista. Thorstein Veblen conecta intimamente as esferas biótica e social. Nesse sentido, ele pôde, então, fixar uma finalidade que dificilmente viria a ser superada por qualquer outra: a sobrevivência da espécie. É exatamente a ela, por exemplo, que ele se refere quando critica a abordagem marxista, propugnadora do direito ao produto total do trabalho. Diz Veblen que, em termos de "causa e efeito”, só se pode argumentar em prol da distribuição que tenha por propósito a sobrevivência de um grupo, de uma civilização, da espécie.

A fixação da sobrevivência da espécie como finalidade última, não no sentido teleológico, mas no sentido de objetivo maior, é uma radicalização que se ajusta muito bem a uma época de incertezas, de argumentos sujeitos a mudanças fundamentais. Seu apelo, que tem um caráter demasiado pragmático, quer ser um alerta para a recorrente confusão entre meios e fins, para a constante adoção de caminhos que divergem do objetivo capital.

Por isso, condenava ele, com veemência, as inclinações “pecuniárias” dos negócios modernos, que teriam exclusivamente como motor a lucratividade, a despeito do bem ou do mal que poderiam causar à "comunidade como um todo". Em oposição, a função “industrial” seria a contraparte da tendência pecuniária, representando uma derivada direta do instinto do trabalho eficaz, conducente à melhoria da sociedade e das condições de vida de todos, ou seja, da espécie. Em $A$ Teoria da Classe Ociosa, Veblen ([1899b], 1994, p. 244) exagera esse caractere de sua teoria, temendo mesmo que a classe ociosa possa comprometer ou dificultar a sobrevivência da espécie, via diminuição da eficiência industrial, pela transmissão 
de traços arcaicos, contraproducentes, "através da herança dentro da classe e por qualquer lugar em que o sangue da classe ociosa sofra transfusão para fora dela”.

Excetuando-se esses trechos, para os quais é possível atribuir um apelo mais retórico, há uma notável consistência do antigo institucionalista norteamericano em argumentar sobre a finalidade essencial em seu sistema. Desse modo, coloque-se:

Veblen radicaliza a finalidade do sistema social como uma ressonância das incertezas e indeterminações percebidas ao tempo da Gilded Age e da Era Progressiva. Sua economia política explicita e alerta sobre um fim maior, o qual parece impossível de ser negado, e que deve estar na raiz de quaisquer outros empenhos humanos.

\section{Notas conclusivas}

A economia de Thorstein Veblen, se confrontada com a epopeia clássica, do modo como foi sugerido no texto inspirador deste artigo, apresenta, sobrepondo-se a outros, um herói-problemático por excelência: a espécie humana.

Sua saga é evidentemente ligada ao mundo natural que a cerca, às condições de possibilidade onde o ramo da árvore das espécies darwiniana pôde crescer e às bases pelas quais a humanidade foi - por um processo que deve ser, por pura causa e efeito, cego em relação a objetivos humanos - selecionada, tanto coletiva como individualmente. Assim, que o intelectual radical e descontente, irrequieto e criativo vai buscar naquilo que talvez tenha sido a teoria científica mais polêmica do seu tempo certezas que a história do país onde vivia misturava, minava, indeterminava.

Contudo, o que foi apresentado acima, muito mais do que estabelecer qual teria sido o herói-problemático da economia política vebleniana, quer falar sobre as circunstâncias nas quais o cientista da economia é levado a compreender o mundo - e seu herói-problemático - para o qual ambiciona montar um quadro, uma história, enfim, uma pletora de peripécias possíveis.

Deseja-se chamar a atenção do leitor, (quase) certamente um economista como Veblen, para o fato de que sua ciência, assim como as outras, tem raízes firmes em seu tempo e seu lugar. Isso não implica que a economia esteja continuamente condenada a pôr-se fora de sua realidade. Se um ponto do plano espaço temporal foi o catalisador de uma compreensão, de uma visão social e econômica do mundo, não decorre diretamente que ele se faça, de imediato, desatualizado com o avançar da história. A única conclusão certa é que se deve estar atento a este fato, a essa determinação inescapável.

\section{Referências bibliográficas}

ABBAGNANO, N. Dicionário de filosofia. 4. ed. São Paulo: Martins Fontes, 2000. 
BARBER, W. American economics to 1900. In: SAMUELS, W. J.; BIDDLE, J. E. e DAVIS, J. B. (Ed.). A companion to the history of economic thought. Malden, Oxford, Melbourne, Berlin: Blackwell Publishing, 2003.

BELL, J. F. História do pensamento econômico. 3. ed. Rio de Janeiro: Zahar, 1982.

BLOOR, D. Knowledge and social imagery. 2. ed. Chicago and London: The University of Chicago Press, 1991.

BLUM, J. M. et al. The national experience: a history of the United States. New York: Hartcourt, Brace and World, 1963.

DORFMAN, J. Thorstein Veblen and his America. New York: The Viking Press, 1947. . The economic mind in American civilization. v. II, III, 1865-1918. New York: The Viking Press, 1949.

DUNBAR, C. Economic science in America. North American Review, Boston, v. 122, n. 250, 1876.

EDWARDS, R. New spirits: Americans in the Gilded Age. Oxford: Oxford University, 2006.

ELY, R. Political Economy in America. North American Review, v. 144, n. 363, 1887.

HANDS, W. Reflection without rules. Economic methodology and contemporary science theory. New York: Cambridge University Press, 2001.

. SSK as a resource for the history of economic thought. HES editorial. Disponível em: http://eh.net/pipermail/hes/1997-January/001615.html. Acesso em: 23 ago. 2008.

HODGSON, G. The evolution of institutional economics. Agency, structure and Darwinism in American Institutionalism. London: Routledge, 2004.

2008.

How Veblen generalized Darwinism. Journal of Economic Issues, v. 42, Jun.

HOFSTADTER, R. The age of reform. New York: Vintage, 1955.

JORGENSEN, E. W.; JORGENSEN, H. I. Thorstein Veblen: victiorian firebrand. Armonk, New York: M. E. Sharpe, 1999.

KNOEDLER, J.; MAYHEW, A. Thorstein Veblen and the Engineers: a reinterpretation. History of Political Economy, v. 31, n. 2, 1999.

LAUGHLIN, J. L. Workingmen's Grievances. North American Review, v. 138, n. 330, 1884.

MAYHEW, A. A reappraisal of the causes of farm protest in United States, 1870-1900. [1972]. In: WHAPLES, R.; BETTS, D. C. Historical perspectives on the American economy: selected readings. New York: Cambridge University, 1995. 
McCORMICK, K. Veblen in Plain English. A complete introduction to Thorstein Veblen's economics. Youngstown: Cambria Press, 2006.

McGERR, M. A fierce discontent: the rise of the progressive movement in America, 18701920. New York: Free Press, 2003.

MONASTÉRIO, L. Guia para Veblen: um estudo acerca da economia evolucionária. Pelotas: EDUFPEL, 1998.

MORGAN, M.; RUTHERFORD, M. American economics: the character of a transformation. History of Political Economy, 30, Supplement, 1998.

NEW SCHOOL UNIVERSITY. History of economic thought website. Disponível em: http://cepa.newschool.edu/het/. Acesso em: jul. 2008.

PARRINGTON, V. Main currents in American thought. Disponível em: www.projectguttenberg.org. [1927]. Acesso em: 25 ago. 2008.

PAUlA, J. A.; CERQUEIRA, H.; ALBUQUERQUE, E. Nações e estilos de economia política. Belo Horizonte: Cedeplar/UFMG, 2001. (Textos para Discussão, n. 160).

ROSS, D. The origins of American social science. New York: Cambridge University Press, 1991.

RUTHERFORD, M. American institutional economics in the interwar period. In: SAMUELS, W. J.; BIDDLE, J. E.; DAVIS, J. B (Ed.). A companion to the history of economic thought. Malden, Oxford, Melbourne, Berlin: Blackwell Publishing, 2003.

SELLER, C. Uma reavaliação da história dos Estados Unidos: de colônia a potência imperial. Rio de Janeiro: Zahar, 1985.

SHAPIN, S.; SCHAFFER, S. Leviathan and the air-pump: Hobbes, Boyle, and the experimental life. Princeton: Princeton University Press, 1985.

TILMAN, R. Thorstein Veblen and the enrichment of evolutionary institutionalism. Columbia: University of Missouri, 2007.

UCHITELLE, L. The Richest of the Rich, Proud of a New Gilded Age. The New York Times, 15 Jul. 2007.

VEBLEN, T. [1898a].Why is economics not an evolutionary science. In: VEBLEN, T. The place of science in modern civilisation and other essays. The collected works of Thorstein Veblen. London: Routledge/Thoemmes Press, 1994.

[1898b]. The instinct of workmanship and the irksomeness of labor. In:

VEBLEN, T. Essays in our changing order. The Collected Works of Thorstein Veblen. London: Routledge/Thoemmes Press, 1994.

[1899a]. The preconceptions of economic science. In: VEBLEN, T. The place of science in modern civilisation and other essays. The collected works of Thorstein Veblen. London: Routledge/Thoemmes Press, 1994. 
VEBLEN, T. [1899b]. The theory of leisure class. The collected works of Thorstein Veblen. Routledge/Thoemmes Press: London, 1994.

. [1901]. Gustav Schmoller's economics. In: VEBLEN, T. The place of science in modern civilisation and other essays. The collected works of Thorstein Veblen. London: Routledge/Thoemmes Press, 1994.

. [1906]. The place of science in modern civilisation. In: VEBLEN, T. The place of science in modern civilisation and other essays. The collected works of Thorstein Veblen. London: Routledge/Thoemmes Press, 1994.

. [1907]. The socialist economics of Karl Marx II. In: VEBLEN, T. The place of science in modern civilisation and other essays. The collected works of Thorstein Veblen. London: Routledge/Thoemmes Press, 1994.

[1908]. Professor Clark’s economics. In: VEBLEN, T. The place of science in modern civilisation and other essays. The collected works of Thorstein Veblen. London: Routledge/Thoemmes Press, 1994.

. [1909]. The limitations of marginal utility. In: VEBLEN, T. The place of science in modern civilisation and other essays. The collected works of Thorstein Veblen. London: Routledge/Thoemmes Press, 1994.

[1914]. The instinct of workmanship and the state of industrial arts. The collected works of Thorstein Veblen. London: Routledge/Thoemmes Press, 1994.

VEIGA, J. E. Evolução darwiniana \& ciências sociais. Estudos Avançados, v. 22, n. 63, 2008.

WEBER, A. F. American economists of today. New England Magazine, v. 21, n. 3, 1899.

WEINTRAUB, R. Roger backhouse’s straw herring. Methodus, v. 4, n. 2, 1992.

WHAPLES, R.; BETTS, D. C. Historical perspectives on the American economy: selected readings. New York: Cambridge University, 1995.

\section{ERRATA:}

No artigo: O surgimento do institucionalismo norte-americano de Thorstein Veblen: economia política, tempo e lugar, publicado no número 1, volume 19 (47), da revista Economia e Sociedade, na página 43, no nome do autor Marco Ribas Cavalieri onde se lê Marco Ribas Cavalieri, leia-se Marco Antonio Ribas Cavalieri. 